International Journal of Instruction e-ISSN: 1308-1470 • www.e-iji.net

Article submission code: 20201209234908

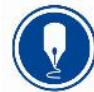

January $2022 \bullet$ Vol.15, No.1

p-ISSN: 1694-609X

pp. 113-134

Received: 09/12/2020

Revision: 05/06/2021
Accepted: 02/07/2021

OnlineFirst: 17/10/2021

\title{
The Effect of Instructional Leadership and Creative Teaching on Student Actualization: Student Satisfaction as a Mediator Variable
}

\section{Muhammad Suyudi}

Institut Agama Islam Sunan Giri Ponorogo, Indonesia, suyudi.insuri@gmail.com

\section{Suyatno}

Universitas Ahmad Dahlan, Indonesia, suyatno@pgsd.uad.ac.id

\section{Azam Syukur Rahmatullah}

Universitas Muhammadiyah Yogyakarta, Indonesia, azam.sy@umy.ac.id

\section{Yulia Rachmawati}

Universitas Ahmad Dahlan, Indonesia, yuliayr8@gmail.com

\section{Nunuk Hariyati}

Universitas Negeri Surabaya, Indonesia, nunukhariyati@unesa.ac.id

$$
\begin{aligned}
& \text { This research was carried out to determine the effect of instructional leadership } \\
& \text { and creative teaching as the main aspects in maximizing student input and } \\
& \text { potential, in order to achieve learning satisfaction and self-actualization for the } \\
& \text { educational success of students. The research examines the effect of principal } \\
& \text { instructional leadership and teaching creativity on self-actualization and its impact } \\
& \text { on student satisfaction. Across sectional study was used to determine the } \\
& \text { relationship between exogenous and endogenous variables. Respondents were } 307 \\
& \text { students on Madrasah Aliyah and Al-Kamal Kebumen Islamic Vocational High } \\
& \text { Schools, Indonesia. Data was collected using a questionnaire consisting of } 4 \\
& \text { indicators representing each variable. The research data was analyzed using } \\
& \text { structural equation modeling (SEM) with the AMOS application. Out of } 5 \\
& \text { proposed hypotheses, } 1 \text { was rejected because of not fulfilling the Critical Ratio } \\
& \text { (CR) value }>1.96 \text { and the p-value <0.05 criteria. The results showed that this } \\
& \text { model fulfilled the Goodness of Fit requirements in SEM analysis. It was evident } \\
& \text { that principal's instructional leadership and creative teaching affects student } \\
& \text { learning satisfaction. The results also showed that the principal's instructional } \\
& \text { leadership affects student self-actualization, while creative teaching has no direct } \\
& \text { effect unless it is mediated by learning satisfaction. }
\end{aligned}
$$

Keywords: instructional leadership, creative teaching, student learning satisfaction, student self-actualization, leadership

Citation: Suyudi, M., Suyatno., Rahmatullah, A. S., Rachmawati, Y., \& Hariyati, N. (2022). The effect of instructional leadership and creative teaching on student actualization: Student satisfaction as a mediator variable. International Journal of Instruction, 15(1), 113-134. https://doi.org/10.29333/iji.2022.1517a 


\section{INTRODUCTION}

Education is a planned effort to create a meaningful climate and learning process for students to develop self-potential, knowledge, attitudes, and skills. According to Maslow (1971), self-actualization is the highest level of human development where one's full potential is realized. Education is one of the best ways of achieving self-actualization. Students with self-actualization optimize their abilities to work beyond expectations (Akcay \& Akyol, 2012; Farimani \& Shahri, 2020; Neto, 2015). Therefore, selfactualization is an achievement towards students' understanding of their full potential and this stage is only achievable when schools maintain quality education. The main factor in realizing student self-actualization success is to maximize existing inputs by providing optimal services to create quality outcomes. This also improves student satisfaction, which is an indicator of the educational institution's quality and potential development. Several research results showed that student satisfaction is an effective method of monitoring the quality of education and academic development (Razinkina et al., 2018; Kammur, 2017). Letcher \& Neves (2010) stated that student satisfaction affects one's self-confidence to develop skills, gain knowledge and achievement, and build pleasant relationships with friends and teachers.

Individuals satisfied with the surrounding environment develops self-actualization abilities (Arslan, 2017). Self-satisfaction created by fulfilling four basic needs, including physiological, security, love, and appreciation, triggers self-actualization (Maslow, 1971). According to Jena and Dorji (2016), job satisfaction also contributes to selfactualization. Efforts to fulfill self-satisfaction mean striving to realize self-actualization. Therefore, when students are satisfied with the learning process, they grow their ability to self-actualize. Achieving student satisfaction and self-actualization requires external motivation and support from parents, school principals, teachers, and peers. Jena and Dorji (2016) stated that teaching wholeheartedly helps students achieve selfactualization through creative and meaningful learning. Furthermore, the principal facilitate quality learning processes for student satisfaction and self-actualization. Tuan (2012) stated that optimal service from school principals impacted student learning satisfaction extensively. Instructional leadership is an intermediary factor in school management that impacts student learning satisfaction (Arif et al., 2013; Kammur, 2017). Moreover, this form of leadership contributes to teacher professionalism and student achievement (Liu \& Hallinger, 2018; Heaven \& Bourne, 2016; Hallinger, 2010).

Instructional leadership is has an influence on various factors that affect student learning satisfaction, such as (a) the formation of a pleasant learning climate in schools (Clifford et al., 2012; Sahney, 2016), (b) improving the quality of cooperation, and communication between schools, teachers, students and parents (Halverson et al., 2007; Park, 2012), and (c) student discipline (Gulcan, 2001). This influence is in line with by the results of other studies which conclude that instructional leadership contributes to the main aspects of learning satisfaction, performance and student achievement (Heaven \& Bourne, 2016; Sahney, 2016; Mitchell \& Tschannen-moran, 2015; Shatzer, 2009; Bartlett, 2008; Moffitt, 2007). On the other hand, teachers' professionalism and pedagogical abilities are also closely related to student learning satisfaction. Teachers 
that carry out creative teaching have the ability to create an innovative and fun learning environment for students, which triggers learning satisfaction. Kangas et al. (2017) stated that learning satisfaction depends on teachers involvement and creativity in teaching. Teachers with the ability to creatively and effectively inspire, motivate and simulate children's learning development are proven to be more able to influence learning satisfaction (Adhikary, 2017; Hemsley-Brown et al., 2010; Rivero, 2002).

This research examined the effects of principal instructional leadership and creative teaching towards student self-actualization mediated by learning satisfaction. Existing research analyzed the relationship between the learning process and students' selfactualization (Farimani \& Shahri 2020; Aljaser, 2019; Velieva et al. 2018; Dmitrienko et al. 2017; Neto 2015; Wadaani 2015; Akcay \& Akyol, 2012). However, realizing students' self-actualization is also the principal's responsibility as the school leader and manager. Therefore, these results can be a reference for principals, teachers, practitioners, and educational officers in developing self-actualization in students.

\section{Literature Review}

\section{Instructional leadership}

Instructional leadership refers to the principal's ability to manage the curriculum and learning to ensure effectiveness and success of the overall educational process. The focus is on involving teachers in curriculum preparation, strategies, and assessment processes to improve the learning quality (Horng \& Loeb, 2010; Lunenbrug, 2010; Marks \& Printy, 2003). Instructional leadership has three aspects, including mission communication, which ensures teachers and staff work based on the school's objective. Furthermore, instructional program management, which includes evaluation, curriculum coordination, and monitoring student progress. The last aspect of instruction leadership is cultivating a positive school climate through teachers' professional development, incentive provision and motivation (Hallinger, 2003; Hallinger, 2010). Blase and Blase (2000) stated that effective instructional leadership has two factors, including communicating with teachers to deepen learning reflection and facilitating professional development. These factors improve teacher performance and professionalism inside and outside the classroom.

The principal's instructional leadership contributes to competence quality and teacher performance because of good planning and learning management. This leadership also affects teacher professionalism and job satisfaction, influencing the student's effectiveness and achievements (Liu \& Hallinger, 2018; Boyce \& Bowers, 2017; Liu et al., 2020). Additionally, instructional leadership influences various students' aspects, including the effective learning environment, cooperation, communication and discipline (Clifford et al., 2012; Sahney, 2016; Park, 2012; Halverson et al., 2007; Gulcan, 2001). Therefore, the principal's instructional leadership is closely related to student achievements and learning satisfaction. This is in line with the research (Heaven \& Bourne, 2016; Sahney, 2016; Mitchell \& Tschannen-moran, 2015; Shatzer, 2009; Bartlett, 2008; Moffitt, 2007) which stated that instructional leadership contributes to learning performance and student achievement. 


\section{Creative teaching}

Creative teaching help students learn new material and practically apply it to life situations. Mayer (1989) stated that learning material provides meaning, heterogeneous abilities, learning methods that stimulate student's creativity, and appropriate learning evaluations to measure student creativity. Horng et al. (2005) reported that learning creativity is influenced by teacher personality, family support, educational experience, belief, hard work, motivation, and school management conditions. Creative teaching is highly influenced by the leadership and management characteristics of school principals. Schools' leadership strategy affects teachers' creativity performance and commitment. Furthermore, the principal's leadership determines school infrastructure development and a work climate that supports teacher creativity (Cachia et al., 2010; Selkrig \& Keamy, 2017).

There are several characteristics of creative teaching namely collaboration, improvisation, and innovation (Sawyer, 2004). Collaboration between teachers and students and amongst students need to be properly developed. For example during class discussions, teachers' improvisation and innovation should be able to facilitate students to build their knowledge. The character of creative teaching is also seen in the teaching selection strategy, namely (a) student-centered learning, (b) varied teaching strategies, (c) classroom management that facilitates diversity and potential of students, (d) teaching that is contextual to everyday life, and (e) accustom students to think critically through question and answer as well as discussion (Horng et al., 2005). According to Jeffrey (2006) creative teaching is also characterized by the relevance of teaching content to the needs and potential of students, including innovation in the presentation of the learning content.

Creative teaching refers to the strategy to foster inventive, effective, and interesting learning, increase students' courage and critical thinking (Corner, 2012; Wood \& Ashfield, 2008; Gibson, 2010). This shows that creative teaching closely relates to learning that develops students' potential. Teachers have the skills to plan, manage, and evaluate appropriate learning to develop student potential in creativity and critical thinking. Habits that can be implemented to foster creative teaching include openness to student thinking, building confidence and safety, stimulating critical thinking, tolerating errors, promoting collaborations, and giving students opportunities to build concepts and solve problems and think across disciplines (Sawyer, 2015). Many studies have concluded that creative teaching affects aspects such as performance, motivation and creativity, cognitive development, experience and learning satisfaction (Schacter et al., 2006; Jankowska \& Atlay, 200; Freund \& Holling, 2008; Strean, 2011; Rivero, 2002).

\section{Student satisfaction and self-actualization}

Learning satisfaction is a measure of services, facilities, and environment, in schools characterized by increased student trust and cooperation (Kammur, 2017; Razinkina et al., 2018). Razinkina et al. (2018) stated that student satisfaction measures academic development, service levels, and education quality in schools. It also shows the quality of the cooperative relationship between schools and parents, which influences student's 
learning satisfaction (Schertzer \& Schertzer, 2004). Several factors affect student learning satisfaction, including innovation, school service quality and principal's instructional leadership (Arif et al., 2013; Elliot \& Healiy, 2001; Kangas et al., 2017; Hemsley-Brown et al., 2010; Teeroovengadum et al., 2019; Tuan, 2012). Furthermore, Bolliger and Martindale (2004) stated that student satisfaction is influenced by factors such as teacher quality, communication with school members, availability of learning technology, and collaboration. Comparably, student satisfaction influences motivation and learning performance, confidence, skill development and self-potential (Letcher \& Neves, 2010; Mihanović et al., 2016). Indicators of student learning satisfaction are seen from several aspects, including (a) improving performance and communication in class (Hahessy et al., 2014), (b) increasing positive feelings and emotions towards the learning process (Cheng et al., 2016), and (c) increasing student response and enthusiasm during learning (Adhikary, 2017).

Self-potential development influenced by student satisfaction is closely related to selfactualization. Maslow (1971) stated that self-actualization is triggered by selfsatisfaction obtained from fulfilling four basic needs, including physiological, security, love, and appreciation. Generally, self-actualization is a prime need in the basic human hierarchy and causes intrinsic motivation to increase self-competence to the highest level. Through education, actualization can be achieved by students gaining learning satisfaction and understanding life goals (Farimani \& Shahri, 2020). Therefore, principals and teachers need skills and proficiency for students to gain learning satisfaction and understanding of their life's purpose. Schools that conduct learning programs to meet student satisfaction, positively influences self-actualization (Akcay \& Akyol, 2012). This is in line with Arslan (2017) and Jena and Dorji (2016), which concluded that students who are satisfied with learning experience increased selfconfidence to develop their potential through self-actualization. Well-being and enthusiasm from self-confidence positively influence self-actualization (Ordun \& Akün, 2017). Students that have reached the self-actualization stage show increased responsibility, learning orientation and motivation, with the ability to control their emotions (Velieva et al. 2018). Furthermore, students 'self-actualization are also seen in their abilities, potentials, and achievements to achieve the learning process (Bulut, 2018; Jena \& Dorji, 2016).

Figure 1 shows the research hypothesis developed based on these descriptions.

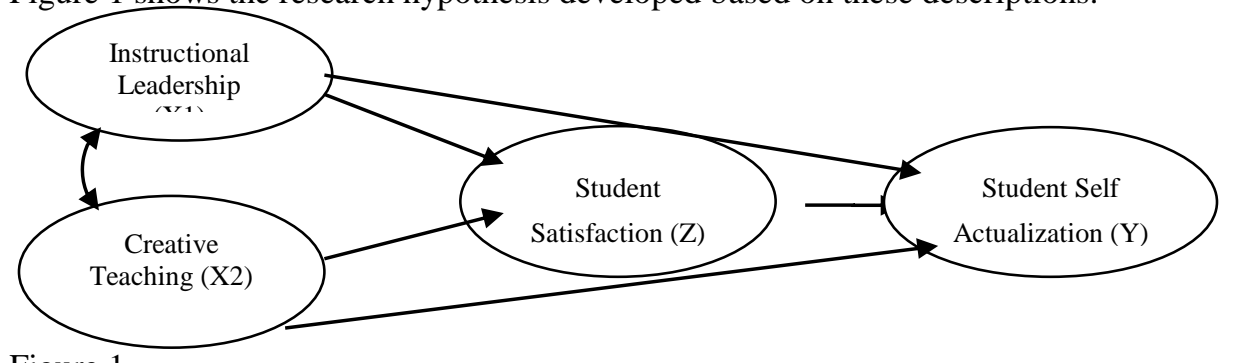

Figure 1

Research hypothesis model scheme 


\section{Research Hypothesis}

This study has five hypotheses, namely:

H1.1: Principal instructional leadership affects student learning satisfaction

H1.2: Creative teaching affects student learning satisfaction

H1.3: Principal instructional leadership affects student self-actualization

H1.4: Creative teaching affects student self-actualization

H1.5: Principal instructional leadership and creative teaching affect student selfactualization mediated by student learning satisfaction

\section{METHOD}

\section{Research design and data collection}

This cross-sectional study aimed to determine the direct or indirect relationship between exogenous and endogenous variables using the SEM, specifically the AMOS analysis model. Respondents were 307 students of Madrasah Aliyah and Al-Kamal Kebumen Islamic vocational high schools, as shown in table 1.

Table 1

Demographics of study respondents

\begin{tabular}{llll}
\hline Profile & Description & Number of Respondents & Percentage \\
\cline { 2 - 4 } Type of School & Madrasah Aliyah & 147 & $48 \%$ \\
\cline { 2 - 4 } & Vocational High School & 160 & $52 \%$ \\
\hline \multirow{2}{*}{ Age } & $14-16$ years & 130 & $40 \%$ \\
\cline { 2 - 4 } & $17-19$ years & 177 & $60 \%$ \\
\hline
\end{tabular}

Data was collected using 4 types of questionnaires representing each variable, including principal instructional leadership, teacher creativity, learning satisfaction and selfactualization. The questionnaire was made using a Likert scale from a score of 1 to 4 , representing strongly disagree, disagree, agree and strongly agree with data collected in intervals. The score is different for negative statements, with 4 for "strongly disagree," 3 for "disagree," 2 for "agree," and 1 for "strongly agree."

\section{Research Instruments}

The study used 2 exogenous variables, including principal instructional leadership and teacher creative learning. Also, there was 1 mediating and endogenous variable represented by student learning satisfaction, and student learning actualization, respectively. The four variables were developed based on the theory described in the previous section. The instrument draft was guided by experts with relevant scientific fields, revised and empirically tested. Study results showed that the instruments had fulfilled the validity and reliability standards. Variables achievements were measured using a questionnaire, where each was categorized in several indicators, as shown in table 2 . 
Table 2

Variable indicator description

\begin{tabular}{|c|c|c|}
\hline Variable & Indicator & Code \\
\hline $\begin{array}{l}\text { Instructional } \\
\text { leadership }\end{array}$ & $\begin{array}{l}\text { 1. Instructional leadership and management programs, including: } \\
\text { - Design and socialization of school vision, mission, goals, and } \\
\text { curriculum } \\
\text { - Management of student activities } \\
\text { - Supervision and evaluation of learning } \\
\text { - Monitoring of student development } \\
\text { 2. School climate management that supports learning } \\
\text { - Management of a school culture that promotes student development } \\
\text { - Training programs that improve the competence of teachers and students } \\
\text { - Appreciation for teacher and student performance } \\
\text { - Social relations with teachers, students, and parents of students }\end{array}$ & IL 1 \\
\hline Creative & 1. Creativity in learning design & CT1 \\
\hline Teaching & $\begin{array}{l}\text { 2. Creativity in learning method determination } \\
\text { 3. Creativity in learning media selection } \\
\text { 4. Creativity in material presentation } \\
\text { 5. Creativity in learning assessment types and tools }\end{array}$ & $\begin{array}{l}\text { CT2 } \\
\text { CT3 } \\
\text { CT4 } \\
\text { CT5 }\end{array}$ \\
\hline $\begin{array}{l}\text { Student } \\
\text { Learning } \\
\text { Satisfaction }\end{array}$ & $\begin{array}{ll}\text { 1. } & \text { Student satisfaction in learning } \\
\text { 2. } & \text { Student satisfaction with school programs } \\
\text { 3. } & \text { Student satisfaction with school infrastructure } \\
\text { 4. } & \text { Student satisfaction with school climate and culture }\end{array}$ & $\begin{array}{l}\text { SS1 } \\
\text { SS2 } \\
\text { SS3 } \\
\text { SS4 }\end{array}$ \\
\hline $\begin{array}{l}\text { Student Self- } \\
\text { Actualization }\end{array}$ & $\begin{array}{ll}\text { 1. } & \text { Self-potential development } \\
\text { 2. } & \text { Problem-solving skills } \\
\text { 3. } & \text { Student creativity } \\
\text { 4. } & \text { Confidence }\end{array}$ & $\begin{array}{l}\text { SA1 } \\
\text { SA2 } \\
\text { SA3 } \\
\text { SA4 }\end{array}$ \\
\hline
\end{tabular}

\section{Data Analysis}

Data was analyzed using Structural Equation Modeling (SEM) with AMOS applications. SEM was used to determine the relationship between instructional leadership, creative learning as exogenous variables with student learning satisfaction as an intervening variable and student self-actualization as an endogenous variable. The advantages of using AMOS and SEM software were image tools, accuracy, speed, and ease of the path analysis (Byrne, 2001). SEM analysis was divided into two categories, including the measurement model, which explains the relationship between variables and their indicators. The second category or the structural model, measures the relationship between different variables (Gerbing \& Anderson, 1988). Also, regression weight output was obtained to determine the acceptable level of the proposed hypothesis.

\section{FINDINGS}

The data analysis results were divided into three categories, including measurement and structural models, and hypothesis testing.

\section{Measurement Model}

The measurement model provided the relationship between instrument values (observed indicator variables) and designed constructs (unobservable latent variables). Furthermore, the model was analyzed using Confirmatory Factor Analysis (CFA) to 
assess variable indicator validity. Indicators were determined from CFA test results with the provisions that the value of CR (critical ration) $>1.96$ and probability or $\mathrm{p}<$ 0.05 . All the variables shown in Table 3 fulfilled the validity test requirements.

\begin{tabular}{|c|c|c|c|c|c|c|c|}
\hline & & & Estimate & SE. & C.R & $\mathbf{P}$ & Labe1 \\
\hline ss & $<--$ & II & $=055$ & .015 & 3.616 & 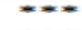 & par_13 \\
\hline ss & $<-\cdots$ & CT & .364 & .032 & 11.271 & $\infty+\infty$ & par_14 \\
\hline SSA & $<-\infty$ & II & .073 & .034 & 2.125 & .034 & par_10 \\
\hline SSA & $<-\cdots$ & CT & -.088 & .149 & -.586 & .558 & par_11 \\
\hline SSA & $<--$ & ss & .799 & .395 & 2,024 & .043 & par_12 \\
\hline IIL 2 & $<--$ & IIL & 1,000 & & & & \\
\hline II 1 & $<-$ & II & $=450$ & .043 & 10.430 & $\infty-\infty$ & par_1 \\
\hline CTS & $<-\cdots$ & CT & 1.000 & & & & \\
\hline CT4 & $<--$ & CT & .502 & .025 & 19.974 & $\infty+\infty$ & par_z \\
\hline CT3 & $<-\infty$ & CT & 1,219 & .058 & 20.973 & $\neq-\infty$ & par_3 \\
\hline$C_{2}$ & $<-\infty$ & CT & $=773$ & .034 & 22.943 & $\infty-\infty$ & par_4 \\
\hline CI1 & $<-$ & $C T$ & 1.511 & .059 & 25.683 & 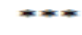 & par_s \\
\hline SSA 1 & $<--$ & SSA & 1,000 & & & & \\
\hline SSA2 & $<-\infty$ & SSA & 2,012 & .146 & 13,784 & $\infty-\infty$ & par_6 \\
\hline $55 A 3$ & $<-\infty$ & SSA & 1.521 & $=114$ & 13.367 & $\neq-\infty$ & par_7 \\
\hline SSA 4 & $<-$ & SSA & 1.575 & .128 & 12.317 & $\cdots$ & par_s \\
\hline SS4 & $<-\cdots$ & ss & 1.000 & & & & \\
\hline 553 & $<-\cdots$ & $s s$ & 1,806 & .169 & 10.674 & $\neq \infty$ & par_15 \\
\hline 552 & $<--$ & $s s$ & 2,310 & .182 & 12,720 & $\cdots$ & par_16 \\
\hline$S S_{1}$ & $<-\cdots$ & ss & 3.457 & .261 & 13.245 & $\neq \infty$ & par_17 \\
\hline
\end{tabular}

Figure 2

$\mathrm{CR}$ and probability values in the CFA test (Note: $* * *=$ p-value $<0,001)$

CR $>1.96$ and probability $<0.05$ from Table 3 show that each indicator fulfilled the validity requirements to represent a variables. Furthermore, the validity test was also conducted to determine the value of standardized loading estimate or loading factor > 0.05 , as shown in table 4 . The results showed that each variable has exceeded the required loading factor value.

\begin{tabular}{|c|c|c|c|}
\hline & & & Estimate \\
\hline$S S$ & $<---$ & II & $=203$ \\
\hline$s s$ & $<---$ & $C T$ & $=778$ \\
\hline$S S A$ & $<---$ & II & $=280$ \\
\hline$S S A$ & $<---$ & $C T$ & $=099$ \\
\hline$S S A$ & $<---$ & $S S$ & 346 \\
\hline II 2 & $<---$ & II & $=926$ \\
\hline II 1 & $<---$ & II & $=670$ \\
\hline CIs & $<---$ & $C T$ & $=907$ \\
\hline$C T_{4}$ & $<---$ & $C T$ & $=816$ \\
\hline $\mathrm{CT}_{3}$ & $<---$ & $C T$ & $=857$ \\
\hline $\mathrm{CT}_{2}$ & $<---$ & $C T$ & $=873$ \\
\hline CI 1 & $<---$ & $C T$ & $=914$ \\
\hline$S S A 1$ & $<---$ & $S S A$ & $=709$ \\
\hline $5 S A 2$ & $<---$ & $S S A$ & $=865$ \\
\hline $5 S A 3$ & $<---$ & SSA & $=831$ \\
\hline$S S A 4$ & $<---$ & $S S A$ & $=756$ \\
\hline $5 S 4$ & $<---$ & SS & $=684$ \\
\hline $5 \$ 3$ & $<---$ & $S S$ & $=724$ \\
\hline $5 \leq 2$ & $<---$ & $s \mathbb{s}$ & $=791$ \\
\hline$S_{S 1}$ & $<---$ & $\mathrm{SS}$ & $=885$ \\
\hline
\end{tabular}

Figure 3

Standardized loading estimate value 


\section{Structural Model}

The structural model described the relationship between all latent variables, including exogenous, intervening, or endogenous. Its validity was measured using the GOF (Goodness of Fit) value or the model's feasibility test, by determining the index suitability criteria achievement and the cut off value. The indices were GFI, AGFI, CMIN/DF, TLI, CFI, and RMSEA. GFI and AGFI described the model suitability level with a value ranging from 0 (poor fit) to 1.0 (perfect fit). According to Arbuckle (2014), GFI $>0.90$ and AGFI $>0.90$ values indicated that the tested model had a good fit. The study obtained a GFI of 0.934 and AGFI of 0.903 , proving that the model was a good fit. Furthermore, CMIN/DF and TLI indicators measured the fit level of the research model with the criteria of CMIN/DF $\leq 2.0$ and TLI $\geq 0.95$ (Byrne et al., 1989). This study's results indicated that the CMIN/DF value was 2.056 and TLI was 0.968 , which shows the model fulfilled the acceptable requirements. Other measurement criteria included CFI, whereby a value closer to 1 provided higher acceptance chances for the model, and RMSEA $\leq 0.08$ (Arbuckle, 2014; Cudeck \& Browne, 1983). These results showed a CFI of 0, 975 and RMSEA of 0.059 which proved a high acceptance level.

Table 3

Goodness of fit indices

\begin{tabular}{llll}
\hline Goodness of Fit Indices & Cut - Off Value & Result Analysis & Model Evaluation \\
\hline CMIN/DF & $\leq 2,00$ & 2,056 & Fit \\
\hline RMSEA & $\leq 0,08$ & 0,059 & Fit \\
\hline GFI & $\geq 0,90$ & 0,934 & Fit \\
\hline AGFI & $\geq 0,90$ & 0,903 & Fit \\
\hline TLI & $\geq 0,95$ & 0,968 & Fit \\
\hline CFI & $\geq 0,95$ & 0,975 & Fit \\
\hline
\end{tabular}

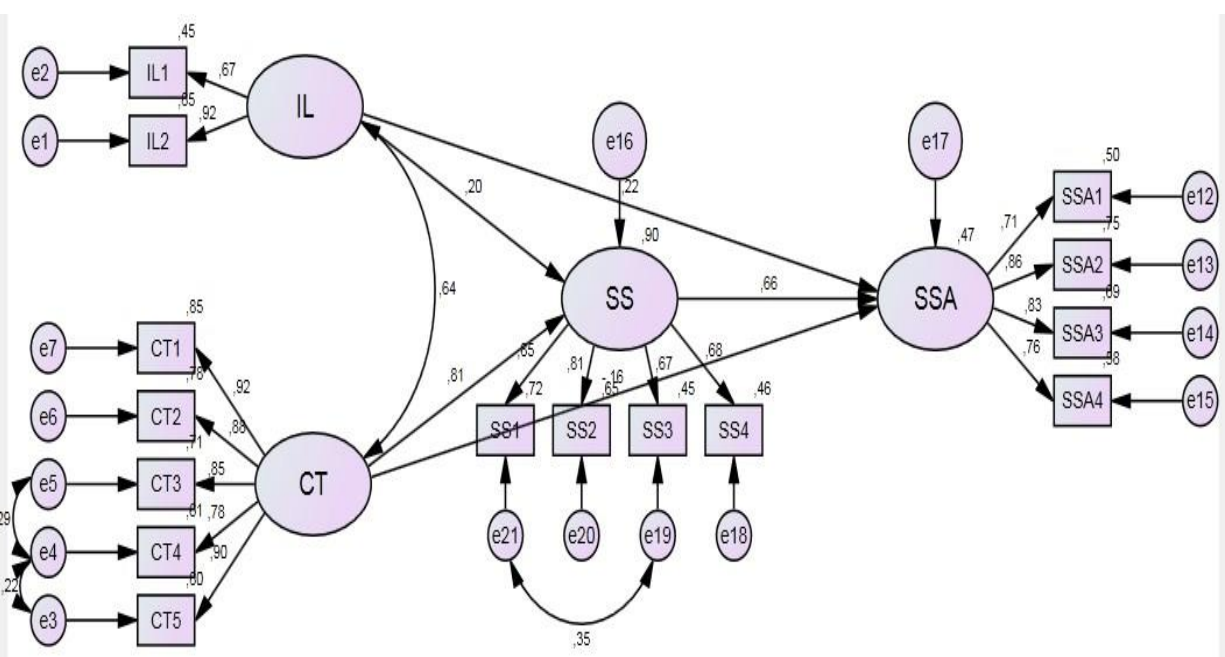

Figure 4

Research model schemes 


\section{Hypothesis test}

Hypothesis testing in SEM AMOS was determined by Critical Ration (CR) and p-value in the regression weights output. $\mathrm{CR}>1.96$ and $\mathrm{p}<0.05$ values proved that this research's hypothesis was acceptable, as shown in Table 6 . The magnitude effect strength between the variables was determined from an existing estimate value.

\begin{tabular}{|c|c|c|c|c|c|c|c|}
\hline & & & Estimate & S.E. & C.R & $\mathbf{P}$ & Label \\
\hline SS & $<---$ & II & .055 & $=015$ & 3,616 & $* * *$ & par_13 \\
\hline SS & $<---$ & $\mathrm{CT}$ & 364 & $=032$ & 11,271 & $* * *$ & par_14 \\
\hline SSA & $<--$ & II &, 073 & $=034$ & 2,125 & $=034$ & par_10 \\
\hline SSA & $<---$ & $\mathrm{CT}$ & $-0,088$ & 149 &,- 586 & .558 & par_11 \\
\hline SSA & $<--$ & SS & $=799$ & $=395$ & 2,024 & .043 & par_12 \\
\hline
\end{tabular}

Figure 5

Regression weight output (Description: $* * *=$ p-value $<0,001$ )

Based on the hypothesis testing, the following evidences were obtained.

1. H1.1: Principal instructional leadership (IL) affects student learning satisfaction (SS). The hypothesis had a CR value of 3,616 and p 0,000 which means the CR value $>1.96$ and $p<0.05$ criteria was met.

2. H1.2: Creative teaching (CT) affects student learning satisfaction (SS). The hypothesis had a CR value of 11.271 and p 0.000 which is acceptable based on CR value $>1.96$ and $\mathrm{p}<0.05$ criteria.

3. H1.3: Principal instructional leadership (IL) affects student self-actualization (SSA). The hypothesis had a CR value of 2.125 and p 0.034 and was accepted based on $C R$ value $>1.96$ and $p<0.05$ criteria.

4. H1.4: Creative teaching (CT) affects student self-actualization (SSA). The hypothesis had a CR value of -5.58 and $\mathrm{p} 0.558$, and was rejected because it did not meet the $\mathrm{CR}$ value $>1.96$ and $\mathrm{p}<0.05$ criteria.

5. H1.5: Principal instructional leadership (IL) and creative teaching (CT) affect student self-actualization (SSA) mediated by student learning satisfaction (SS). The hypothesis had a CR value of 2.024 and p 0.043 which was accepted based on CR value $>1.96$ and $\mathrm{p}<0.05$ criteria.

\section{DISCUSSION}

This research model met the criteria for a good fit model to determine the effects between variables. Table 6 shows that out of the 5 proposed hypotheses, only 1 was rejected. The description of the hypothesis test can be described as follows:

Principal instructional leadership (IL) has a significant direct effect on student learning satisfaction (SS) and student self-actualization (SSA)

The hypothesis of the IL effect on SS was accepted because it met the CR value> 1.96 and $\mathrm{p}<0.05$ criteria. Instructional leadership manages education quality by involving teachers in curriculum preparation, learning strategies and assessments (Horng \& Loeb, 2010; Lunenbrug, 2010; Marks \& Printy, 2003). Therefore, a principal leads to quality 
learning by providing optimal services to develop student talents and full potential. Optimal service to students affects student learning satisfaction. Teeroovengadum et al. (2019), Kammur (2017) and Tuan (2012) concluded that student satisfaction and commitment depend on the quality of educational services provided by schools in facilitating their potential and talents. Furthermore, the principal leadership in learning management improves student performance that leads to satisfaction. This is in line with previous research results (Bartlett, 2008; Heaven \& Bourne, 2016; Mitchell \& Tschannen-moran, 2015; Moffitt, 2007; Sahney, 2016; Shatzer, 2009). Students appreciate and enjoy good performance and achievement which improves their satisfaction levels. Moreover, instructional leadership influences various aspects related to students, including the formation of a pleasant learning environment, improved communication and student discipline (Clifford et al., 2012; Sahney, 2016); Halverson et al., 2007; Park, 2012; Gulcan, 2001). This aspect shows that IL is closely related to the supporting factors of student learning satisfaction. Quality collaboration and school communication with students correlates with their learning satisfaction (Arif et al., 2013; Bangert 2005; Elliot \& Healiy, 2001). Other studies showed that the principal's instructional leadership improves the quality of educational services which tends to impact on student learning satisfaction. The higher the quality of service, the higher the student's learning satisfaction (Hasan et al., 2009; Kammur, 2017; Tuan, 2012). Involving students in various work programs and school activities creates a sense of pride and satisfaction because they feel appreciated and important.

Instructional leadership influenced students' self-actualization because its effect on SSA was acceptable and met CR value $>1.96$ and $p<0.05$ criteria. IL is the key to success in managing the learning process because it provides excellent service for students' potential development. Several student potentials are affected by IL, including creativity, innovation and entrepreneurial spirit making them highly competitive. The development of students' self-potential through instructional leadership is an effective step to self-actualization (Sharma, 2012; Yavgildina et al. 2019). Through IL, schools can develop modern and innovative strategies, services, and learning environments to keep up with students' needs. Leadership and educational services that adjust to the times, school programs and students' needs positively affect self-actualization (Akcay \& Akyol, 2012; Dmitrienko et al., 2017). According to preliminary studies, instructional leadership contributes to improving learning performance and student achievement (Heaven \& Bourne, 2016; Sahney, 2016; Mitchell \& Tschannen-moran, 2015; Shatzer, 2009; Bartlett, 2008; Moffitt, 2007). This is because improved learning performance and student achievement is an indicator of the self-actualization stage. Several studies stated that the indicators of realizing students' self-actualization is seen from the increase in their ability, potential, and achievement (Bulut, 2018; Jena \& Dorji, 2016).

Creative teaching (CT) has a direct effect on student learning satisfaction (SS) but has no direct effect on student self-actualization (SSA)

The hypothesis of the CT effect on SS was accepted because it met the CR value> 1.96 and $\mathrm{p}<0.05$ criteria. Therefore, creative teaching directly affects student learning satisfaction. Creative teaching refers to a teaching strategy to foster inventive, effective, 
and interesting learning as well as increasing students' courage and critical thinking skills (Corner, 2012; Gibson, 2010; Wood \& Ashfield, 2008). It gives students the freedom to explore and build a meaningful learning process. Therefore, students easily achieve their goals, which influence learning satisfaction. The achievement of learning objectives is also supported by a fun and dynamic climate in creative teaching. Bangert (2005) stated that creative teaching provides climate and student learning flexibility, which impacts satisfaction. Several studies conclude that creative teaching affects learning satisfaction by improving student achievement, motivation and creativity, cognitive development and experiences (Freund \& Holling, 2008; Jankowska \& Atlay, 2008; Schacter et al., 2006; Trean, 2011). Creative teaching helps students realize their potential to solve learning and life problems independently. Students' self-potential and independence are the successes of creative teaching and learning satisfaction. Lee (2011) stated that creative and innovative teaching significantly affects student learning satisfaction. Moreover, it affects the school environment and makes learning enjoyable. Kangas et al. (2017) stated that a fun learning process determines the level of learning satisfaction. Teachers with the ability to creatively and effectively inspire, motivate and simulate children's learning development are proven to be more able to influence learning satisfaction (Adhikary, 2017; Hemsley-Brown et al., 2010; Rivero, 2002).

This study proved that creative teaching does not directly affect students' selfactualization based on the hypothesis test of the CT effect on SSA which was rejected. However, creative teaching affected students' self-actualization when mediated by learning satisfaction. Student self-actualization was determined by learning satisfaction influenced by the creative teaching and principal instructional leadership. According to Rivero (2002), creative teaching affects student learning satisfaction. Bolliger and Martindale (2004) stated that the teaching quality and creative use of technology correlates to student learning satisfaction. Therefore, creative teaching influencing students 'self-actualization when inventive potential is well developed. This is in line with Velieva et al. (2018), which stated that students' self-actualization is realized when learning needs are successfully understood and developed. Learning needs awareness motivates students to develop their potential, increase creativity, and independence to self-actualize (Neto, 2015). The teaching process is the only supporting factor for the formation of this awareness. Students' self-actualization requires a complete change in the education system at school and at home for its realization. The alignment of the education system at school and at home affects their ability to reach the selfactualization stage (Dmitrienko et al., 2017). Furthermore, this stage cannot be achieved assuming there are many psychological obstacles that students get from the social environment, especially their families. Therefore, it is difficult to be able to realize student self-actualization despite the provision of a creative teaching process to overcome these obstacles (Bulut, 2018).

Instructional leadership (IL) and creative teaching (CT) influence student selfactualization (SSA) mediated by student learning satisfaction (SS)

Instructional leadership and creative teaching affect self-actualization mediated by student satisfaction. This hypothesis had a CR value of 2.024 and p 0.043, which 
acceptable based on CR value $>1.96$ and $\mathrm{p}<0.05$ requirements. Instructional leadership and creative teaching provide opportunities for students to develop their knowledge, skills, and potential. The two factors also make the learning process enjoyable by involving students in designing optimal educational services. Therefore, instructional leadership and creative teaching develop students' skills and potential, making them happy which grows their learning satisfaction. Maslow (1971) stated that selfsatisfaction obtained from fulfilling four basic needs, including physiological, security, love, and appreciation, triggers self-actualization growth. Because learning satisfaction is a basic psychological need, achievements help students self-actualize. Akcay and Akyol's research (2012) proved that schools that implement learning programs to meet student satisfaction help them fulfill self-actualization needs. Arslan (2017) and Jena and Dorji (2016) concluded that students satisfied with the learning experience increased self-confidence to develop their potential through self-actualization. Moreover, through self-confidence, students grow enthusiasm for self-actualization (Ordun \& Akün, 2017).

Generally, principal's leadership oriented towards quality learning and teacher creativity influences student satisfaction. Because self-actualization is a prime goal in the learning process, principals need to focus on instructional leadership and improving teacher creativity.

\section{CONCLUSION}

This research achieved suitability and conformity demands because the model met the good fit test requirements. The study results proved a relationship between exogenous, intervening, and endogenous, such that the principal's instructional leadership and creative teaching affect student learning satisfaction. Furthermore, the principal's instructional leadership influences students' self-actualization, while creative teaching has no direct effect. The principal instructional leadership and creative teaching influence self-actualization mediated by student learning satisfaction. Therefore, educational policymakers and curriculum designers need quality learning-oriented leadership for students' satisfaction and potential actualization.

\section{ACKNOWLEDGMENT}

The authors express gratitude to the Sidogiri Ponorogo Islamic Institute, Ahmad Dahlan University, Yogyakarta Muhammadiyah University, and Surabaya State University for supporting the implementation of research and article writing.

\section{REFERENCES}

Adhikary, J. R. (2017). Leadership style and student satisfaction: Mediation of teacher effectiveness. Asian Journal of Business and Management, 5(2), 62-69. https://doi.org/10.24203/ajbm.v5i2.4632

Akcay, C., \& Akyol, B. (2012). Self actualization needs and education of participants in lifelong education centers. Procedia - Social and Behavioral Sciences, 46(2011), 34563459. https://doi.org/10.1016/j.sbspro.2012.06.084 
Aljaser, A. (2019). Examining the implications of differentiated instruction for high school students' self-actualization. International Journal of Education and Practice, 7(3), 184-199. https://doi.org/10.18488/journal.61.2019.73.184.199

Arbuckle, J. L. (2014). IBM SPSS Amos 23.0 user's guide. AMOS Development Corporation.

Arif, S., Ilyas, M., \& Hameed, A. (2013). Student satisfaction and impact of leadership in private universities. TQM Journal, 25(4), 399-416. https://doi.org/10.1108/17542731311314881

Arslan, A. (2017). Basic needs as a predictors of prospective teachers' selfactualization. Universal Journal of Educational Research, 5(6), 1045-1050. https://doi.org/10.13189/ujer.2017.050618

Bangert, A. W. (2005). Identifying factors underlying the quality of online teaching effectiveness : An exploratory study. Journal of Computing In Higher Education, 17(2), 79-99. https://www.researchgate.net

Bartlett, J. C. (2008). Principal leadership practices: A correlation study of spesific instructional leadership practice and student achievement on the tennessee gateway tests (Issue May). Liberty University.

Blase, J., \& Blase, J. (2000). Effective instructional leadership. Journal of Educational Administration, 38(2), 130-141. https://doi.org/10.1108/09578230010320082

Bolliger, D. U., \& Martindale, T. (2004). Key factors for determining student satisfaction in online courses. International Journal on E-Learning, 61-67. https://doi.org/10.5771/9783845279893-1090-1

Boyce, J., \& Bowers, A. J. (2017). Toward an evolving conceptualization of instructional leadership as leadership for learning. Journal of Educational Administration. https://doi.org/10.1108/JEA-06-2016-0064

Bulut, S. S. (2018). Obstacles to self-actualization of college students-the case of gazi faculty of education. Universal Journal of Educational Research, 6(10), 2271-2279. https://doi.org/10.13189/ujer.2018.061026

Byrne, B. M. (2001). Structural equation modeling With AMOS, EQS, and LISREL: Comparative approaches to testing for the factorial validity of a measuring instrument. International Journal of Testing, 1(1), 55-86. https://doi.org/10.1207/s15327574ijt0101_4

Byrne, B. M., Shavelson, R. J., \& Muthén, B. (1989). Testing for the Equivalence of Factor Covariance and Mean Structures: The Issue of Partial Measurement Invariance. Psychological Bulletin, 105(3), 456-466. https://doi.org/10.1037/0033-2909.105.3.456

Cachia, R., Ferrari, A., Ala-Mutka, K., \& Punie, Y. (2010). Creative learning and innovative teaching. In JRC Scientific and Thechnical Reports. https://doi.org/10.2791/52913 
Cheng, M., Taylor, J., Williams, J., \& Tong, K. (2016). Student satisfaction and perceptions of quality: testing the linkages for $\mathrm{PhD}$ students. Higher Education Research and Development, 35(6), 1153-1166. https://doi.org/10.1080/07294360.2016.1160873

Clifford, M., Behrstock-Sherratt, E., \& Fetters, J. (2012). A synthesis of research on principal influence to inform performance evaluation design. A Qualiy School Leadership, 3(Brief).

Corner, C. (2012). Into another world: From creativity to creative learning. Improving Schools, 15(2), 116-129. https://doi.org/10.1177/1365480212450237

Cudeck, R., \& Browne, M. W. (1983). Cross-validation of covariance structures. Multivariate Behavioral Research, 18(2), 147-167. https://doi.org/10.1207/s15327906mbr1802_2

Dmitrienko, N. A., Gorbina, M. A., Porozhnyak, N. F., Trusova, T. V., \& Konovalenko, T. G. (2017). Formation of students' professional self-actualization in modern educational environment. Journal of Social Studies Education Research, 8(2), 161-177. https://doi.org/10.17499/jsser.360871

Elliot, K. M., \& Healiy, M. A. (2001). Key factors influencing student satisfaction related to recruitment and retention. Journal of Marketing for Higher Education, 10(4), 1-11. https://doi.org/10.1300/J050v10n04

Farimani, Z. B., \& Shahri, N. N. (2020). Reaching Self-actualization in Education: Construction and Validation of a Hierarchical Scale. Journal of Language Teaching and Research, 11(4), 623. https://doi.org/10.17507/j1tr.1104.14

Freund, P. A., \& Holling, H. (2008). Creativity in the classroom: A multilevel analysis investigating the impact of creativity and reasoning ability on GPA. Creativity Research Journal, 20(3), 309-318. https://doi.org/10.1080/10400410802278776

Gerbing, D. W., \& Anderson, J. C. (1988). Structural equation modeling in practice: A review and recommended two-step approach. Psychological Bulletin, 103(3), 411-423. http://psycnet.apa.org/psycinfo/1989-14190-001

Gibson, R. (2010). Points of departure: The "art" of creative teaching: Implications for higher education. Teaching in Higher Education, 15(5), 607-613. https://doi.org/10.1080/13562517.2010.493349

Gulcan, M. G. (2001). Research on instructional leadership competencies of school principals. Education, 132(3), 625-636.

Hahessy, S., Burke, E., Byrne, E., Farrelly, F., Kelly, M., Mooney, B., \& Meskell, P. (2014). Indicators of student satisfaction in postgraduate blended learning programmes: Key messages from a survey study. The All Ireland Journal of Teaching and Learning in Higher Education, 6(3). 
Hallinger, P. (2003). Leading educational change: Reflections on the practice of instructional and transformational leadership. Cambridge Journal of Education, 33(3), 329-351. https://doi.org/10.1080/0305764032000122005

Hallinger, P. (2010). Developing Instructioal Leadership. In Developing Successful Leadership (pp. 61-76). https://doi.org/10.1007/978-90-481-9106-2

Halverson, R., Grigg, J., Prichett, R., \& Thomas, C. (2007). The new instructional leadership: Creating data-driven instructional systems in school. Journal of School Leadership, 17(3), 159-194.

Hasan, H. F. A., Ilias, A., Rahman, R. A., \& Razak, M. Z. A. (2009). Service quality and student satisfaction: A case study at private higher education institutions. International Business Research, 1(3), 163-175. https://doi.org/10.5539/ibr.v1n3p163

Heaven, G., \& Bourne, P. A. (2016). Instructional leadership and its effect on students' academic performance. Review of Public Administration and Management, 04(03). https://doi.org/10.4172/2315-7844.1000197

Hemsley-Brown, J., Lowrie, A., Gruber, T., Fuß, S., Voss, R., \& Gläser-Zikuda, M. (2010). Examining student satisfaction with higher education services: Using a new measurement tool. International Journal of Public Sector Management, 23(2), 105123. https://doi.org/10.1108/09513551011022474

Horng, B. Y. E., \& Loeb, S. (2010). New Thinking about instructional. Kappan, 92(3), $66-70$.

Horng, J. S., Hong, J. C., Chanlin, L. J., Chang, S. H., \& Chu, H. C. (2005). Creative teachers and creative teaching strategies. International Journal of Consumer Studies, 29(4), 352-358.

Jankowska, M., \& Atlay, M. (2008). Use of creative space in enhancing students' engagement. Innovations in Education and Teaching International, 45(3), 271-279. https://doi.org/10.1080/14703290802176162

Jeffrey, B. (2006). Creative teaching and learning: Towards a common discourse and practice. Cambridge Journal of Education, 36(3), 399-414. https://doi.org/10.1080/03057640600866015

Jena, P. C., \& Dorji, R. (2016). Self-actualization and value orientation among primary school teachers in Bhutan. World Scientific News, 54, 217-239.

Kammur, A. A. (2017). The quality of educational services and its effect on students satisfaction an empirical study on students of alrifaq private university in Libya. Global Journal of Commerce \& Management Perspective, 6(1), 1-10. https://doi.org/10.24105/gjcmp.6.1.1701

Kangas, M., Siklander, P., Randolph, J., \& Ruokamo, H. (2017). Teachers’ engagement and students' satisfaction with a playful learning environment. Teaching and Teacher Education, 63, 274-284. https://doi.org/10.1016/j.tate.2016.12.018 
Lee, Y. J. (2011). A study on the effect of teaching innovation on learning effectiveness with learning satisfaction as a mediator. World Transactions on Engineering and Technology Education, 9(2), 92-101.

Letcher, D., \& Neves, J. (2010). Determinants of undergraduate business student satisfaction. Research in Higher Education Journal, 1-26. http://scholar.google.com/scholar?hl=en\&btnG=Search\&q=intitle:Determinants+of+und ergraduate+business+student+satisfaction\#0

Liu, S., \& Hallinger, P. (2018). Principal instructional leadership, teacher self-efficacy, and teacher professional learning in china: Testing a mediated-effects model. Educational Administration Quarterly, 54(4), 501-528. https://doi.org/10.1177/0013161X18769048

Liu, Y., Bellibaş, M. Ş., \& Gümüş, S. (2020). The effect of instructional leadership and distributed leadership on teacher self-efficacy and job satisfaction: mediating roles of supportive school culture and teacher collaboration. Educational Management Administration and Leadership, $\quad X X(\mathrm{X}), \quad 1-24$. https://doi.org/10.1177/1741143220910438

Lunenbrug, F. C. (2010). The Principal as Instructional Leader: An Evolving Role. National Forum Of Education And Supervision Journal, 27(4). https://doi.org/10.1177/019263658506948107

Marks, H. M., \& Printy, S. M. (2003). Principal leadership and school performance: an integration of transformational and instructional leadership. Educational Administration Quarterly, 39(3), 370-397. https://doi.org/10.1177/0013161X03253412

Maslow, A. (1971). Self Actualizing. Big Sur Recordings.

Mayer, R. E. (1989). Cognitive views of creativity: Creative teaching for creative learning. Contemporary Educational Psychology, 14, 203-211.

Mihanović, Z., Batinić, A. B., \& Pavičić, J. (2016). The link between students' satisfaction with faculty, overall students' satisfaction with student life and student performances. Review of Innovation and Competitiveness, 2(1), 37-60. https://doi.org/10.32728/ric.2016.21/3

Moffitt, J. R. (2007). What Works: Principal Leadership Behaviors that Positively Impact Student Achievement in Elementary Schools. Electronic Theses and Dissertations. https://digitalcommons.georgiasouthern.edu/etd/264

Neto, M. (2015). Educational motivation meets Maslow: Self- actualisation as contextual driver. Journal of Student Engagement: Education Matters, 5(1), 18-27. http://ro.uow.edu.au/jseemhttp://ro.uow.edu.au/jseem/vol5/iss1/4

Ordun, G., \& Akün, F. A. (2017). Self actualization, self efficacy and emotional intelligence of undergraduate students. Journal of Advanced Management Science, 5(3), 170-175. https://doi.org/10.18178/joams.5.3.170-175 
Park, J. H. (2012). The effects of principal's leadership style on support for innovation: Evidence from Korean vocational high school change. Asia Pacific Education Review, 13(1), 89-102. https://doi.org/10.1007/s12564-011-9182-9

Razinkina, E., Pankova, L., Trostinskaya, I., \& Pozdeeva, E. (2018). Student satisfaction as an element of education quality monitoring in innovative higher education institution. In E3S Web of Conferences, 33(03043).

Rivero, L. (2002). Progressive digressions: Home schooling for self-actualization. Roeper Review, 24(4), 197-202. https://doi.org/10.1080/02783190209554180

Sahney, V. D. S. (2016). School leadership and its impact on student achievement: The mediating role of school climate and teacher job satisfaction. International Journal of Educational Management, 30(6). https://doi.org/http://dx.doi.org/10.1108/IJEM-122014-0170

Sawyer, K. (2015). A call to action: The challenges of creative teaching and learning. Teachers College Record, 117(10), 1-34.

Sawyer, R. K. (2004). Creative teaching: Collaborative discussion as disciplined improvisation. Educational Researcher, 33(2), 12-20. https://doi.org/10.3102/0013189X033002012

Schacter, J., Thum, Y. M., \& Zifkin, D. (2006). How much does creative teaching enhance elementary school students' achievement? Journal of Creative Behavior, 40(1), 47-72. https://doi.org/10.1002/j.2162-6057.2006.tb01266.x

Schertzer, C. B., \& Schertzer, S. M. . (2004). Student satisfaction and retention: A conceptual model. Studies in Higher Education, 7(1), 37-41. https://doi.org/10.1300/J050v14n01

Selkrig, M., \& Keamy, R. (2017). Creative pedagogy: a case for teachers' creative learning being at the centre. Teaching Education, 28(3), 317-332. https://doi.org/10.1080/10476210.2017.1296829

Sharma, S. (2012). Instructional Leadership Model through Asian Principals , Perspectives. 2012 International Conference on Education and Management Innovation, 30, 17-21.

Shatzer, R. H. (2009). A comparison study between instructional and transformational leadership theories: Effects on student achievement and teacher job satisfaction [Brigham Young University December]. In All Theses and Dissertations. https://scholarsarchive.byu.edu/etd/2432 This

Strean, W. B. (2011). Creating student engagement? HMM: Teaching and learning with humor, music, and movement. Creative Education, 02(03), 189-192. https://doi.org/10.4236/ce.2011.23026

Teeroovengadum, V., Nunkoo, R., Gronroos, C., Kamalanabhan, T. J., \& Seebaluck, A. K. (2019). Higher education service quality, student satisfaction and loyalty: Validating 
the HESQUAL scale and testing an improved structural model. Quality Assurance in Education, 27(4), 427-445. https://doi.org/10.1108/QAE-01-2019-0003

Tuan, N. M. (2012). Effects of service quality and price fairness on student satisfaction. International Journal of Business and Social Science, 3(19 October), 132-151. https://www.academia.edu/9764615/Effects_of_Service_Quality_and_Price_Fairness_o n_Student_Satisfaction

Velieva, S. V., Mashkin, N. A., Khairullina, E. R., Semenova, T. N., Varlamova, M. E., Guseva, T. S., \& Dolgasheva, M. V. (2018). University student professional selfactualization: Context of personality subjectivity. Espacios, 39(20).

Wadaani, M. R. (2015). Teaching for Creativity as Human Development toward SelfActualization: The Essence of Authentic Learning and Optimal Growth for All Students. Creative Education, 06(07), 669-679. https://doi.org/10.4236/ce.2015.67067

Wood, R., \& Ashfield, J. (2008). The use of the interactive whiteboard for creative teaching and learning in literacy and mathematics: A case study. British Journal of Educational Technology, 39(1), 84-96. https://doi.org/10.1111/j.14678535.2007.00703.x

Yavgildina, Z. M., Batyrshina, G. I., Kamalova, I. F., Salakhova, R. I., \& Salakhov, R. F. (2019). Pedagogical conditions for the creative self-actualization of future art teachers. International Journal of Civil Engineering and Technology, 10(2), 16771685.

\section{Research Instrument}

Questionnaire 1. Student Self-Actualization

\begin{tabular}{lllll}
\hline No & Statement & \multicolumn{2}{l}{ Score } \\
\hline 1 & I acquire new knowledge while studying at school & 1 & 2 & 3 \\
\hline 2 & $\begin{array}{l}\text { I was not opportune to participate in determining the activities in the } \\
\text { class / school }\end{array}$ & 1 & 2 & 3 \\
\hline 3 & I try to improve myself when I make mistakes with friends and teachers & 1 & 2 & 3 \\
\hline 4 & The school helps me to develop my potential & 1 & 2 & 3 \\
\hline 5 & The facilities in this school support me to develop my potential & 1 & 2 & 3 \\
\hline 6 & I had the opportunity to improve my skills & 1 & 2 & 3 \\
\hline 7 & $\begin{array}{l}\text { I had the opportunity to participate in determining the programs in the } \\
\text { classroom / school }\end{array}$ & 1 & 2 & 3 \\
\hline 8 & The school didn't give me anything new & 1 & 2 & 3 \\
\hline 9 & I motivate myself to acquire the best performance in school & 1 & 2 & 3 \\
\hline 10 & I was not opportune to improve my skills & 1 & 2 & 3 \\
\hline 11 & I strive to maintain and develop my achievements & 1 & 2 \\
\hline 12 & $\begin{array}{l}\text { The school does not provide opportunities for me to develop my } \\
\text { potential }\end{array}$ & 1 & 2 & 3 \\
\hline 13 & I am ignorant of my achievements and do not try to improve them & 1 & 2 \\
\hline
\end{tabular}


Questionnaire 2. Student Learning Satisfaction

\begin{tabular}{|c|c|c|}
\hline No & Statement & Score \\
\hline 1 & I have a deep understanding of the material I study in class & (1) 23 \\
\hline 2 & $\begin{array}{l}\text { Learning in the classroom emphasizes the mastery of knowledge and skills } \\
\text { in a balanced manner }\end{array}$ & 1234 \\
\hline 3 & $\begin{array}{l}\text { Each student is given the same opportunity to participate in class } \\
\text { discussions and ask questions }\end{array}$ & (1) 34 \\
\hline 4 & $\begin{array}{l}\text { Every student in the class has the same opportunity to try to work on the } \\
\text { questions given by the teacher }\end{array}$ & $123(4)$ \\
\hline 5 & $\begin{array}{l}\text { The teacher acts as a facilitator in the classroom, while students are } \\
\text { actively involved in learning. }\end{array}$ & $123(4)$ \\
\hline 6 & $\begin{array}{l}\text { The teacher does not only explains the theory but also emphasizes the } \\
\text { mastery of students' attitudes and skills }\end{array}$ & (1) 34 \\
\hline 7 & $\begin{array}{l}\text { The teacher gives strict punishment to students that fail to carry out their } \\
\text { homework }\end{array}$ & (1) 3 (4) \\
\hline 8 & I always carry out my teacher's assignments diligently and seriously & (1) 23 \\
\hline 9 & $\begin{array}{l}\text { The teacher delivered the material clearly therefore, I didn't have to search } \\
\text { for more sources from other books }\end{array}$ & 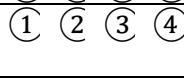 \\
\hline 10 & $\begin{array}{l}\text { The lessons at school have provided me with in-depth materials therefore I } \\
\text { do not have to take extra lessons outside the school }\end{array}$ & $123(4)$ \\
\hline 11 & The school climate really supports me to study with all my heart & (1) 23 \\
\hline 12 & $\begin{array}{l}\text { The facilities and infrastructure in the school are complete to support the } \\
\text { learning process }\end{array}$ & (1) 34 \\
\hline 13 & The teacher in the class gave me the opportunity to take the follow-up & \\
\hline
\end{tabular}

14 The teacher assigns scores to students objectively and in accordance with their individual abilities

15 The relationship between students in the class is compact and helps each 1 (2) (3) (4) other

16 Classmates are not excluded when attending lessons despite having $\quad$ (1) (2) (4) limitations in these subjects

17 Teachers in schools have the ability to teach and master the material being (1) (2) (4) taught

18 The teacher teaches in an interactive and fun way, therefore, the classroom (1) (2) (4) atmosphere is not tense

\section{Questionnaire 3. Teacher Creativity in Teaching}

\begin{tabular}{|c|c|c|}
\hline No & Statement & Score \\
\hline 1 & $\begin{array}{l}\text { In opening lessons, the teacher attracts students' attention enthusiastically } \\
\text { and warmly }\end{array}$ & (1) (2) (4) \\
\hline 2 & $\begin{array}{l}\text { In opening lessons, the teacher links the current subject matter with the } \\
\text { previous material }\end{array}$ & (1) (2) (4) \\
\hline 3 & $\begin{array}{l}\text { The teacher uses media when explaining the subject matter in front of the } \\
\text { class }\end{array}$ & (1) (2) (4) \\
\hline 4 & The media used by teachers varies & (1) (2) (4) \\
\hline 5 & The teacher uses creative methods to solve problems in class & (1) (2) (4) \\
\hline 6 & $\begin{array}{l}\text { The learning method applied by the teacher increases interaction in the } \\
\text { teaching and learning processes }\end{array}$ & (1) (2) (4) \\
\hline
\end{tabular}




\begin{tabular}{|c|c|c|}
\hline 7 & The teacher provides questions to students according to the subject matter & (1) (2) (4) \\
\hline 8 & $\begin{array}{l}\text { Questions from the teacher were given warmly and enthusiastically to } \\
\text { students }\end{array}$ & (1) (2) (4) \\
\hline 9 & $\begin{array}{l}\text { The teachers convey material creatively, thereby attracting students' } \\
\text { interest in learning }\end{array}$ & (1) (2) (4) \\
\hline 10 & $\begin{array}{l}\text { The teachers can use learning media creatively, thereby making the } \\
\text { material presented more concrete and clear }\end{array}$ & (1) (2) (4) \\
\hline 11 & $\begin{array}{l}\text { The teacher is creative in the use of learning media therefore, the } \\
\text { teaching and learning process becomes more lively }\end{array}$ & (1) (2) (4) \\
\hline 12 & The teachers use quality and varied learning resources & (1) (2) (4) \\
\hline 13 & $\begin{array}{l}\text { The teacher uses the simulation method in the teaching and learning } \\
\text { process }\end{array}$ & (1) (2) (4) \\
\hline 14 & $\begin{array}{l}\text { The teachers are skilled in carrying out variations of learning such as the } \\
\text { use of various learning resources and methods }\end{array}$ & (1) (2) (4) \\
\hline 15 & $\begin{array}{l}\text { The teacher creates and modifies teaching media for appropriate learning } \\
\text { needs and attracts students' interest. }\end{array}$ & (1) (2) (4) \\
\hline 16 & $\begin{array}{l}\text { After the lesson, the teacher gives directions to students to learn the lesson } \\
\text { that will be discussed for the next meeting }\end{array}$ & (1) (2) (4) \\
\hline 17 & $\begin{array}{l}\text { If students have difficulty answering, the teacher provides guidance, } \\
\text { therefore, the student has a picture of the expected answer }\end{array}$ & (1) (2) (4) \\
\hline 18 & $\begin{array}{l}\text { The teacher chooses teaching methods that is creative and in accordance } \\
\text { with the subject matter as well as the conditions of the students }\end{array}$ & (1) (2) (4) \\
\hline 19 & $\begin{array}{l}\text { The teacher provides e } \\
\text { in everyday life. }\end{array}$ & (1) (2) (4) \\
\hline 20 & The teacher plans follow-up activities in the form of learning & (1) (2) (4) \\
\hline \multicolumn{3}{|c|}{ Questionnaire 4. Principal Instructional Leadership } \\
\hline No & Statement & Score \\
\hline 1 & $\begin{array}{l}\text { The principal involves students in developing curriculum and educational } \\
\text { goals in schools }\end{array}$ & (1) (2) (4) \\
\hline 2 & $\begin{array}{l}\text { The principal carry out outreach on students regarding the goals of } \\
\text { education at the school }\end{array}$ & (1) (2) (4) \\
\hline 3 & $\begin{array}{l}\text { The principal provides opportunity for students to have an opinion } \\
\text { related to themselves or extracurricular activities }\end{array}$ & (1) (2) (4) \\
\hline 4 & $\begin{array}{l}\text { The principal provides support and guidance to the school program held } \\
\text { by students }\end{array}$ & (1) (2) (4) \\
\hline 5 & $\begin{array}{l}\text { The principal carries out routine monitoring of the learning process in the } \\
\text { classroom }\end{array}$ & (1) (2) (4) \\
\hline 6 & $\begin{array}{l}\text { The principal provides direction and motivation to students to make them } \\
\text { successful in their learning }\end{array}$ & (1) (2) (4) \\
\hline 7 & $\begin{array}{l}\text { The principal provides support for activities that increase the potential of } \\
\text { students }\end{array}$ & (1) (2) (4) \\
\hline 8 & $\begin{array}{l}\text { The principal provides directions to teachers and students to create an } \\
\text { orderly learning climate in the classroom }\end{array}$ & (1) (2) (4) \\
\hline 9 & The principal regularly evaluates each teacher and staff & (1) (2) (4) \\
\hline 10 & $\begin{array}{l}\text { The principal invites students or their guardians to discuss the } \\
\text { development and progress of learning }\end{array}$ & (1) (2) (4) \\
\hline 11 & The principal provides the opportunity for students to take part in various & (1) (2) (4) \\
\hline
\end{tabular}


activities capable of increasing their competence

12 The principal does not motivate students to participate in activities that 1 (2) (3) (4) can increase their competence

13 The principal provides services to students related to their various affairs (1) (2) (4) at school

14 The principal shows concern to the problems faced by students and $\quad$ (1) (2) (3) (4) involves them in solving these problems

15 The principal does not hesitate to invite students to collaborate in 1 (2) (3) (4) realizing the vision and mission of the school

16 The principal is not friendly and familiar with students $\quad$ (1 (2) (3) (4)

17 The principal is always responsive to the problems of students and 13 (2) (3) parents

18 The principal does not appreciate the success achieved by students 4 (1) (3) (4) 